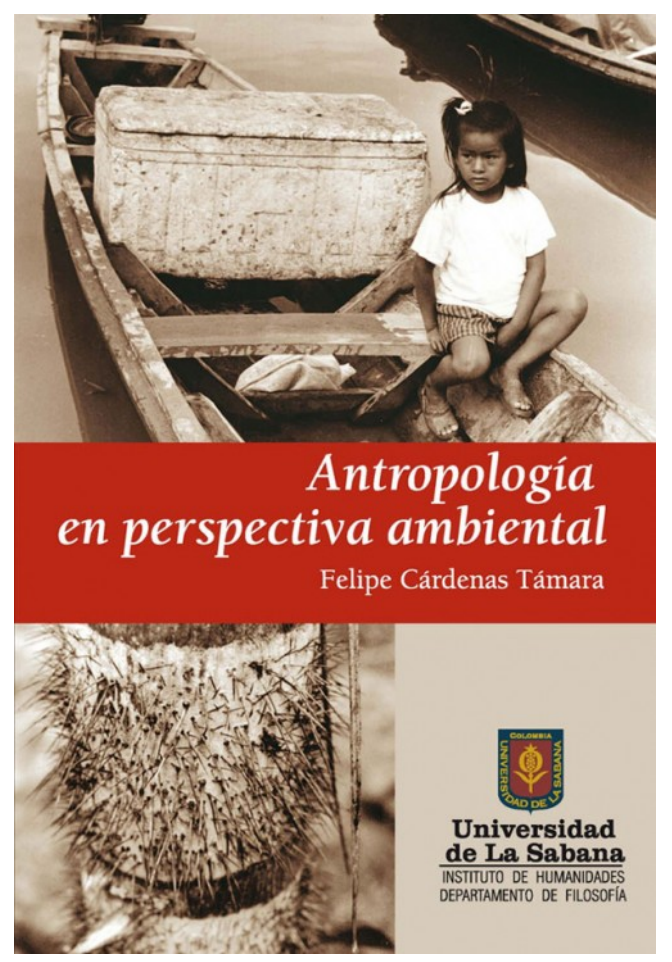

\title{
ANTROPOLOGÍA EN PERSPECTIVA AMBIENTAL
}

Por: Felipe Cárdenas Támara

Formato: Digital

ISBN: 978-958-12-0243-0

Facultad: Filosofía y Ciencias Humanas

Idioma: Español

Precio en dólares: USD $\$ 4,99$

Número de páginas: 302

Palabras clave: Antropología, Crisis ambiental, Perspectiva ecológica

\section{$\$ 11.900$}

\section{Reseña del Producto}

En este trabajo se reúnen una serie de visiones referidas a un ejercicio de descripción, comprensión e interpretación de la relación ecosistema-cultura desde un enfoque ecléctico que se nutre y reconoce la importancia de los modelos de la ciencia natural, de los enfoques sociales y de interpretaciones hermenéuticas y fenomenológicas para definir estrategias de investigación-gestión sobre el territorio y la cultura.

\section{Información Adicional}

Sku: 9789581202430

\section{Tabla de contenido}

PRÓLOGO

PRESENTACIÓN

CAPÍTULO I

LA PERSPECTIVA ECOLÓGICA EN ANTROPOLOGÍA

La perspectiva ecológica

Ecolog.as no reduccionistas en el campo de la antropología

Conclusiones

Actividad de aprendizaje

CAPÍTULO II

EL PAISAJE ADIVINATORIO DE LOS KOGI

La Sierra Nevada y su historia

El contexto adivinatorio

Los kogi y la adivinación

La adivinación en el mundo mítico

Yatukua o adivinar con agua

Nociones adivinatorias 
Conclusiones

Actividad de aprendizaje

CAPÍTULO III

CRISIS AMBIENTAL Y CRISTIANISMO

Introducción

Aspectos preliminares del problema

Dilema bíblico y teología ambiental

Las promesas y desafíos en el Nuevo Testamento

Testimonios de la tradición cristiana

El papel de la parroquia

De los tesoros del patrimonio de nuestra Iglesia:

la parroquia de la Iglesia Ortodoxa Etíope

Ideas finales

CAPÍTULO IV

INDIOS, CURAS E IMAGINARIOS CAMPESINOS

Antecedentes históricos

Geograf.as de la esperanza

Tradición oral

Reflexiones en torno a la tradición oral

Fiestas patronales y religiosas

Lugares de peregrinación

Conclusiones

Actividad de aprendizaje

CAPÍTULO V

MUNDOS RURALES CAMPESINOS

Ser campesino: elementos conceptuales

Funciones de la familia campesina

Las perspectivas ecológicas

Historia ambiental de la familia campesina: norte de Boyacá. - Colombia

Entre lo rural y lo urbano: itinerarios personales de un "campesino"

La migración campesina

Tipos de migración

Conclusiones

Actividad de aprendizaje

CAPÍTULO VI

AGONÍA Y RESURGIMIENTO DEL CULTIVO DE LA QUINUA EN COLOMBIA

Orígenes de la domesticación de la quinua

Distribución prehispánica

Historia reciente del cultivo en Colombia

Problemas del desarrollo rural sostenible

Desarrollo rural y demanda energética

Elementos teóricos para construir paisaje

La ruptura del modelo extensionista

El problema comunicativo

Estrategia y programa de acción

Cosmología cristiana y plano locutorio

Hacia la redefinición del papel del hombre en el cosmos

El plano locutorio

Difusión del cultivo de la quinua en Chita (Boyacá.)

Historias de vida de la quinua: testimonios

Expresión religiosa en el municipio de Chita

Síntesis de la información

Conclusiones

Actividad de aprendizaje

A MANERA DE CONCLUSIÓN

BIBLIOGRAFÍA 